\title{
Mandibular Prominence
}

National Cancer Institute

\section{Source}

National Cancer Institute. Mandibular Prominence. NCI Thesaurus. Code C34204.

An embryonic structure developing from the lower part of the first pharyngeal arch, which gives rise to the mandible. 